\title{
The Evolution of the Modern Vocational Training Systems in England and Germany: a comparative view
}

\author{
THOMAS DEISSINGER, University of Mannheim, Germany
}

\section{The "Background": features and characteristics of the two systems}

With the coming of the European Common Market vocational education and training have become an issue of general concern. As European societies perceive that both the quantity and quality of education and training provision can be seen as factors of an economy's efficiency and competitiveness the educational experiences of other countries continue to receive close attention (Lowe, 1992, p. 581.). Since the time of the Industrial Revolution England has been aware that its educational system lags behind European competitors. Up to the present day scholars and policy-makers have not tired of stressing the need for "closing the gap" and with it also for a radical reform of vocational training and education (Perry, 1976). The deficiencies of the system by which England trains its workers have not merely been regarded as one of the major causes of the economy's poor productivity (Prais, 1989). In the wake of the crises challenging the European economies in the seventies and eighties it also became evident that youth unemployment was increasingly conditioned by shortages in the amount and level of qualifications for skilled employment provided by the training system. In contrast, countries with a dual system of vocational training, such as Germany, Austria and Switzerland, faced less serious problems with regard to the integration of young school-leavers into work (Casey, 1983). Even though the British rate of youth unemployment no longer ranges among the highest within the European Community, in 1990 it was still at $9.3 \%$, i.e. twice as high as Germany's (Statistisches Amt der EG, 1992, p. 120). Data from the 1987 Labour Force Survey reveal that in general young people were twice as severely haunted by the problem of finding a job or by lay-offs as the 25-49 age group, while youth unemployment itself varied with the scale and level of general and vocational qualifications. Unemployment among those in the 16-19 age group who had no qualifications at all was nearly twice as high as among those possessing qualifications (N.N., 1988, p. 559). With the Carr Report of 1958 and the "Great Debate" which led to the Industrial Training Act the topic was already on the agenda of post-war educational policy when, in 1963, Lady Williams characterized the state of vocational training in England (Williams, 1963, p. 7):

1. There is no supervision of training by any outside authority, and as there is no test at the end it is impossible to know how many apprentices reach a 
minimum standard of competence.... 2. There is very little provision for actual instruction. An apprentice is expected to pick up his knowledge by watching others.... 3. Day release is not compulsory and it is estimated that not more than $30 \%$ of apprentices get it. This proportion varies greatly from one industry to another.... 4. The majority of firms take no interest in the progress of their apprentices at the technical college even if they do give them time to attend.

Nevertheless Lady Williams suggested that the best firms in England offered training "which is as good as that found anywhere in the world; but there is no means of knowing what proportion of apprentices get this good training" (ibid.). This problem is still paramount. One of its causes may be seen in the "instability of British apprenticeship" which continues to be linked to "increases in relative pay and training quality and falls in volume" (Marsden \& Ryan, 1991, p. 262). Comparisons between England's output of skilled workers and that of its European competitors reveal that school-leavers in England predominantly pass to employment or stay on at school instead of entering the vocational training system. In January 1987, 43\% of 16-18-year-olds had been in employment as against $17 \%$ who had decided to continue their general or academic education at school. Just $12 \%$ had embarked on Youth Training and no more than $11 \%$ on Further Education (DES, 1988, p. 25). Yet as Youth Training is a product of the Thatcher administration it cannot be regarded as a natural component of what may be called the English "training culture" which traditionally covers two sectors:

(i) The system of Further Education, a term introduced into legislation by the 1944 Education Act, which provides a wide range of part-time and full-time general and vocational courses at Local Education Authority colleges (Dent, 1983, p. 131).

(ii) The system of industrial apprenticeship which is determined by ancient tradition since the Middle Ages and still represents the traditional pattern of vocational training (initial training) in a variety of craft and industrial occupations (Lewis, 1981, pp. 38-40).

As an institution apprenticeship has declined in the recent past. Whilst in 1968 236,000 apprentices had embarked on initial training in manufacturing industry, in 1987 this number had dropped to far less than 100,000 (Hough, 1987, p. 105). And whereas in Germany initial training contracts (abgeschlossene Ausbildungsverträge) in the dual system rose by $19 \%$ between 1964 and 1986, the British record scored at $26 \%$ of the 1964 level. One of the most significant characteristics of English vocational training is the lack of commitment on the side of employers to provide for adequate training opportunities. This feature differs sharply from the "long-standing and highly regulated participation" of German employers in the dual system (Noah \& Eckstein, 1988, p. 62). The latter indeed does command confidence because employers are willing to train young people who, on the other hand, regard apprenticeship as the best route into adult employment. Here the system's stability is due to training being seen as preceding a job whereas in England, by tradition, it is delivered within the context of "making money" (Hurrelmann \& Roberts, 1991, p. 233). Undoubtedly the decline of apprenticeships in England is also due to the fact that they work on the principle of "time-serving" and thus have remained "interwoven in the fabric of industrial relations" (Liepmann, 1960, p. 13): the average wage of a British apprentice in the metal-working sector (as a percentage of that of a skilled worker) tops the German figure by more than $100 \%$. In 
engineering, apprentice allowances in Germany amount to $35.2 \%$ of a skilled worker's pay, whereas the ratio in Britain is at $72.5 \%$ (Marsden \& Ryan, 1991, p. 259).

With the Youth Training Scheme (YTS), introduced in 1983 (Hitchcock, 1988, p. 70) and now labelled Youth Training (YT), the Thatcher government looked determined to tackle the problem of integrating young persons into work by setting up a framework for industrial training subsidized from public resources. In the face of soaring youth unemployment, which reached its peak in 1982/83 (Raffe, 1987), financial incentives were considered to make the scheme attractive to employers who would otherwise not have participated. YT was born out of crumbling confidence in the economy's ability to build up a training infrastructure on its own which would be strong enough to cope with the challenges produced by technological and economic change. As before in 1964 and 1973 YT represented an adjustment of the government's policy concerning the education of post-16-year-olds. It was directed at unemployed school-leavers, guaranteeing training and planned work experience in a firm which also involves off-the-job training in a college. However, the scheme was introduced in haste and-like its predecessor YOP (Youth Opportunities Programme)-it continues to have a number of "quality control problems" (Raggatt, 1988, p. 179). YT is not built on the premises typical for the dual system of Germany. When it came into operation employers did not wish to see local or regional authorities, let alone the government, take over any functional responsibility in the field of vocational training. Over the last decades, however, employers have not shed their reluctance to invest into training because they have a "deep-rooted fear of anyone they train being poached" (Warner, 1990). Unsurprisingly their attitude became more favourable when the government announced that it would provide the scheme's financial backing.

The term "dual system" refers to an institutional framework including legal provisions and training arrangements which is determined by the partnership of two "learning venues": the firm providing the apprenticeship and the vocational school (Deutscher Ausschuss, 1966, p. 418). The system is more complex than the term indicates as it includes a network of private, semi-private and public interests and responsibilities including the trade unions and, above all, the chambers (of industry and commerce, the crafts and the professions) who are in charge of monitoring in-company training and of holding exams. Thus the dual system has much of the character of a rather heteronomous educational sub-system clearly segregated from the school system (Kutscha, 1990). As in England, vocational training is based on the principle that, in the first place, it ought to be the concern of companies and not part of the government's duties. However, whereas in England on-the-job-training is merely complemented by off-the-job-training on a voluntary basis, in Germany it is mandatory. State Education Acts (Landesschulgesetze) set up the legal framework which ensures that youngsters are kept within the educational system after leaving school at the age of 16 (from the Hauptschule) or 17 (from the Realschule). Everybody under the age of 18 not in Higher or Further Education has to attend the local part-time vocational school (Berufsschule) on a sandwich or day-release basis. As a matter of fact, everybody commencing an apprenticeship is required to stay on at school until the end of the training period, which normally stretches over 3 years (Elser \& Kramer, 1987, pp. 50-53).

The vocational school links apprenticeship to the educational system and steers it along educational as well as training lines. Moreover, the law of training--laid down by federal legislation in the Vocational Training Act of 1969 (Berufsbildungsgesetz) - demands that apprentices must not be merely employed but have to be trained via a course of planned in-company training over a specified period of time. At present 374 
"recognized skilled occupations" (Ausbildungsberufe) have been based on "training ordinances" (Ausbildungsordnungen) which include general guidelines, the order of training contents, the length of apprenticeship as well as the examination requirements at the end of the training period (Benner, 1977). Training ordinances are the formal responsibility of the Federal Ministry of Education and Science. For each recognized occupation the Länder of the Federal Republic work out syllabuses (Rahmenlehrpläne) underlying the theoretical instruction which takes place at the part-time vocational school. The Vocational Training Act, on the other hand, stipulates the rights and duties of trainees and training companies and the technical and personal qualifications required of training personnel. It also obliges firms to release their trainees from work for attendance at the vocational school (Zabeck, 1985, p. 676). This state-controlled, yet market-driven approach to industrial training possesses the advantage that a great number of school-leavers obtain marketable qualifications which entitle them to embark on various employments within their occupational context (Greinert, 1988, p. 149). The system is almost universal since it comprises about three quarters of 16-19-year-olds. In 1991, some 540,000 young people entered an apprenticeship after German employers had offered some 669,000 training places. Currently, there are roughly 1.6 million apprentices learning their trades in re-united Germany (Bundesminister für Bildung und Wissenschaft, 1992, pp. 120, 138).

Reasons for the small output of skilled workers in England, where neither a college course nor YT confer the acceptance of young people as "skilled" (Hurrelmann \& Roberts, 1991, p. 242), can be seen both in the absence of a comparable legal framework for in-company training and in the lack of obligatory part-time schooling for apprentices and trainees. It may be expected that without the latter "many employers will go on offering employment to youngsters in dead-end jobs without training" as surveys reveal that "they do not regard training or general skills as part of their business" (Layard \& Prais, 1990). Compared with Germany the decrease in high-quality traineeships and the absence of governmental responsibility beyond the provision of financial incentives for companies who increase training opportunities are due to the different role played by the state (Raggatt, 1988, p. 176):

Whereas in Germany the law is regarded as guaranteeing rights, in England legislation is viewed as restricting rights. Hence where the role, responsibilities and obligations of the participants including structures for cooperation in the dual system are set out in law there is very little comparable legislation in England. The law, then functions as a primary source of quality control in Germany. The system established in law provides continuity with the past building on established models and traditions.

The organisation of vocational training in England and Wales has become fairly diffused since authority has been shifted to a range of autonomous bodies. Although the government has intervened in the field of vocational training in various ways since 1964, when the nation's laissez-faire attitude to training ceased, its market-mindedness, however, has not vanished. Indeed, neither the Industrial Training Act (Page, 1967) nor the Employment and Training Act (Perry, 1976, pp. 301-305) can be described as deserving the name of a "training revolution": By mid-1991 the number of statutory Industrial Training Boards had been reduced to three (Twining, 1992, p. 36). In the meantime the Manpower Services Commission-now called the Training Agency-had been transformed into a body under the auspices of the Department of Employment tackling unemployment on behalf of the government (Dunford \& Sharp, 1990, p. 99). 
The duties of both institutions have recently been transferred to 82 Training and Enterprise Councils (TECs) established in 1989 to lay the major responsibility for vocational training back on the shoulders of English employers (Mathieson, 1992, p. 197). This new approach is supported by the idea of localizing responsibilities for training by involving local firms into the process of identifying training needs. It clearly corresponds with the overall objective of the British government's training policy to give employers the lead and say in all aspects of training (Twining, 1992, p. 29). According to a recent training survey carried out for the Industrial Society, employers take little interest in the new system of National Vocational Qualifications (NVQs) set up in 1986 to reform and rationalize vocational qualifications in England and Wales (Ellis \& Gorringe, 1989). Although NVQs are meant to be "employment led" and have been designed to induce more young people to opt for the vocational route into employment rather than for the A-level "gold standard" acceptance of the system is said to be low [1]. A study carried out for the Department of Employment in 1990/91 concludes that NVQs lack the quality of occupation-based qualifications. According to the author, their narrowness "highlights the conflicts between the short-term needs of employers and the long-term interests of industry, the economy, and the individual: a conflict which underpins the whole notion of employer led training" (Callender, 1992, p. 34).

YT, which is now under the management of TECs, has certainly filled a gap in quantitative terms in that it annually offers training to some 300,000 16-year-olds. But it is still under attack from critics who say that it serves more as a tool to curb youth unemployment and as a source of cheap labour than as a proper training scheme. The prominent shortage areas on the labour market, i.e. craft and technician skills, can be attributed to the fact that the government has predominantly focused on the importance of workplace-based training following "the announced goal of prizing young workers into jobs and training". Looked at from this background, YT can hardly be considered a substitute for the declining system of apprenticeship: not least because of "the scheme's indifference to educational objectives" and the fact that quality control has remained a "matter of form rather than content" (Marsden \& Ryan, 1991, pp. 265-267). A recent study for the Anglo-German Foundation claims that the quality aspect of vocational training in England still depends fundamentally on the legal as well as the didactical dimension of a system delivering a vocational preparation that "finishes too soon and at too low a level for the individuals' or the economy's long-term good" (Hurrelmann \& Roberts, 1991, p. 241). More worryingly, the number of 16- and 17-year-olds who entered the labour market on a direct route in 1989/90 was 497,000 as against 281,000 joining YT (Twining, 1992, p. 60).

The following sections try to give a brief outline of the development of the German and English systems of vocational training. The different characteristics to which we have directed our attention have been formed over time, emerging from traditions that are deeply rooted in the history of the two nations, particularly as they are linked to their respective industrial development in the nineteenth century. Both countries stuck to the pattern of skill formation which evolved at the beginning of our century. We may call the roots of this pattern the "training culture". Whereas in England the evolution of vocational training was mainly a product of social and economic change (Deissinger, 1992), in Germany the state as a law-making and law-enforcing agent contributed greatly to the forging of what is now called the dual system. 


\section{Germany's Way: looking back to the old order}

The history of vocational training in Germany may be subdivided into five phases. The first period refers to the apprenticeship system of the guilds which, as in England, arose in the Middle Ages (Stratmann, 1967, p. 37) and, though degenerating, continued to exist far into the nineteenth century. The second phase marks the era of liberalisation reaching its legislative peak in 1869 . The third period commences in 1897 with the revival of the system of apprenticeship sanctioned and promoted by the Wilhelmine State. The fourth phase is determined by the emergence of formalized vocational training in industry, above all in the $1920 \mathrm{~s}$ and $1930 \mathrm{~s}$, following chiefly the lines of the handicraft apprenticeship system. The beginning of the fifth period is hallmarked by the passing of the Vocational Training Act in 1969 which finalized the course of development beginning in 1897 by re-affirming the chambers as major agents of firm-based training. The emergence of this highly structured training system has been accompanied by the consolidation (didactical and institutional) of the part-time vocational school since the beginning of our century and the succeeding enactment of part-time compulsion.

\subsection{The Revival of the System of Apprenticeship}

For an explanation of why apprenticeship in Germany still represents the major route into skilled employment it is necessary to look back to the Wilhelmine Empire, which emerged from the Franco-German War in 1871. Although the period between 1850 and 1873 in general may be described as the continent's industrial "coming-of-age" (Landes, 1969 , p. 93 ) the Kaiserreich (1871-1918) undoubtedly marks the actual rise of German industrial society. It was under the leadership of the Prussian State that Germany entered "the complex of commercial and industrial Europe in the nineteenth century" (Veblen, 1954 , p. 151). Prior to this Germany had been seeking to come to terms with a pre-industrial situation characterized by a time lag of at least half a century against the British economy. With the assistance of British technology and British engineers Germany managed to catch up, not least by imitating British production methods. Both in Prussia and in the Southern states such as Württemberg or Baden, however, this was made possible and thoroughly promoted by the governments who had become involved with Gewerbeförderung, an economic policy linked to "good schools" and to the formal training of mechanics and engineers. In 1834, the Zollverein (Customs Union) paid tribute to the liberal cause by quickening the development of private enterprises following the lifting of trade restrictions between seventeen German states (Heaton, 1964, pp. 556-559).

As to industrial legislation, the situation up to 1869 is confusing. The Imperial Handicraft Act of 1731 (Stratmann, 1967, pp. 208-211) as well as the Allgemeine Landrecht for the Prussian States of 1794 (Stratmann \& Schlüter, 1982, p. 41) had both re-affirmed the principles of medieval craftsmanship by placing apprenticeship under the auspices of the guilds. The latter, however, also mentioned the so-called Freimeister (free masters) recognized by the government and thus extended the entitlement to train to unorganized artisans and to those trades that were no longer subject to guild control. In 1810/11, in Prussia, guild privileges were removed and freedom of trade implemented as a general principle (Stratmann, 1982, p. 178), although reality remained determined by diverging regulations in the other states which had formed the Holy Roman Empire until 1806. In 1845, the Prussian Trade Act (Stratmann \& Schlüter, 1982 , p. 122), though not repealing freedom of entrepreneurship as a whole, re-imposed 
restrictions on free craftsmanship in that it confined the privilege to take apprentices in as many as 43 trades to masters who belonged to a guild (formerly called Zunft, now Innung). The Act of 1849 made a distinction between small workshops and industrial premises linking the right to take and train apprentices in handicraft occupations to examined journeymen. The definition of apprentice, however, was extended to "everybody who enters an employment with a master to learn a trade" notwithstanding whether he paid a premium or became a wage-earner (Stratmann \& Pätzold, 1984, pp. 117-119).

After these half-hearted intermezzi, freedom of enterprise was finally incorporated in the Gewerbeordnung of the North German Federation in 1869 (Schlüter \& Stratmann, 1985 , p. 145). The Act not only re-affirmed freedom of trade but also the private character of apprenticeship which was defined as a contract between Meister and Lehrling. For craft apprentices it merely stated that the apprentice was subjected to an employer whose task it was to instruct and employ him. The guilds, although they never had been abolished as institutions, were not assigned any rights or duties with respect to industrial training. As a matter of fact, the guilds lost their official status as public institutions which had been confirmed by preceding trade legislation (Kiesewetter, 1989, p. 55). The Gewerbeordnung remained silent as to the issue of what was to raise the status of an apprentice above the juvenile who worked for wages (Stratmann, 1991, p. 372).

In the late nineteenth century events of an essentially political nature began to influence the fate and further development of vocational training in the German Empire. During the first half of the century the ambition of governments had been to promote trade and industry by dedicating all political energy, according to the absolutist traditions of German principalities, to the community's material prosperity (Veblen, 1954, p. 174). Looking at the Kaiserreich there can be no doubt that the Prussian tradition made sure that those traditional authoritarian structures distinguishing the German pattern of political genesis from that of Western societies (Müller, 1989, p. 10) also became deeply entrenched into the process of social formation. The Wilhelmine Empire, like its Prussian predecessor, adopted the principles of an Ordnungsstaat which succeeded in binding major social groups, above all the so-called Mittelstand, loyally to the state and its institutions, not least "as a vehicle for some much-needed popular support against the Socialists" (Eley, 1978, p. 131). The Mittelstandsbewegung (small-business movement) mainly consisted of small-scale entrepreneurs in handicraft, commerce, retailing and transportation, who, both socially and politically, constituted an influential pressure group. On the one hand, even as late as $189558 \%$ of manufacturing and retailing firms were one-man businesses (Blackbourn, 1977, p. 420). On the other, the Mittelstand was well represented in the Reichstag where the National Conservatives, the Catholic Centre Party and parts of the National Liberal Party succeeded in pushing through a course of conservative legal amendments (Winkler, 1976, pp. 1-3). As to industrial legislation, its tendency was anti-liberal, anti-capitalist, anti-socialist and protectionist (Nipperdey, 1990, p. 258). It was held that it made sense to grant economic privileges in return for the Mittelstand's political value to the state (Blackbourn, 1977, p. 421).

The protective legislation between 1881 and 1897 has to be set against the background of Mittelstandspolitik since it was directed to revising the liberalist trade law passed in 1869 and extended to the Empire in 1871. The changes it brought about have been well documented in social historiography and may be summarized as follows (Winkler, 1976, p. 2): 
In 1881 , craftsmen achieved the legal recognition of their guilds, which, by the same law, also received certain privileges in the training of apprentices. In 1884 , another law provided, in certain circumstances, the restriction to guild members of the right to have apprentices. By far the most important imperial handicraft law was that of 1897 , which introduced handicraft chambers as institutions of public law and the so-called compulsory guild option (fakultative Zwangsinnung). This meant that membership in a guild became obligatory if the majority of the independent craftsmen of a given branch in a given chamber district so decided.

The 1897 Act is called "Handwerkerschutzgesetz" since, in a time of industrial and commercial expansion, its objective was to "defend" the independent artisan against the "Große Industrie" (Marx, 1974, p. 391). It was claimed that the "social question" was owing to the fact that many artisans had become victims of free trade and industrialism. By reverting to the medieval ideal of the Handwerkerstand (craftsman's profession) working in the "good old workshop" legislation was to restore what industrial life had destroyed. A major aspiration of its protagonists was to re-introduce Befähigungsnachweise (certificates of skill achievement) for the legal pursuit of a handicraft trade and for the taking of apprentices. Although it did not prescribe the Meisterbrief (master's certificate) as a training prerequisite, the Act of 1897 (Schlüter \& Stratmann, 1985, p. 210) revived some of the old apprenticeship regulations. The newly established chambers and guilds were to become involved with training matters and to hold examinations for journeymen or masters. The Act also made provision for the technical qualification required for the training of apprentices by confining it to skilled journeymen of at least 24 years of age who had either served a three-year apprenticeship or pursued their trades for at least five years as independent artisans. Indentures became general practice in the craft sector as well as the three-year training period, at the end of which the apprentice should have the opportunity to take his examination (Stratmann \& Pätzold, 1984, p. 123). The Handwerkerschutzgesetz laid the foundations of the corporatist framework typical of the dual system. Ironically, the "new system of industrial training" emerged in a climate of anti-industrial agitation and its contents and contours were shaped not by the bearers of industrialisation but by pre-industrially minded pressure groups who sought to preserve the idea of Beruf (vocation) [2] in a world of accelerated change (Blankertz, 1969, p. 127).

The Act was not the last chapter in the formation of the modern German system of vocational training. In 1908, the "protectionist forces accomplished another partial success" when the right to train apprentices was restricted to examined handicraft masters (Winkler, 1976, p. 2). In 1953, the Handwerksordnung (Handicraft Act) summarized the preceding handicraft legislation by making provisions affecting vocational training in general and the taking and instruction of apprentices in particular. It also contained a list of 111 trades that were defined as Handwerksberufe (Benner, 1987, p. 281). After the First World War industrial employers' organisations, too, had started to work out Berufsbilder (occupational profiles) which were the precursors of present training ordinances. From 1930, the Chambers of Industry and Commerce began to hold exams for skilled workers, which until then had been the exclusive right of the handicraft guilds and chambers. In due course industrial employments and apprenticeships had to be systematized and classified. By 1937 some 100 trades had been based on uniform skill profiles which underpinned skilled workers' examinations (ibid., p. 273). The distinction between skilled, semi-skilled and unskilled occupations was 
to determine the framework for apprenticeships in industrial firms for more than 30 years. With the passing of the Vocational Training Act in 1969, which ended the divergent developments in the craft and the industrial sector, the term Ausbildungsberuf eventually replaced this terminology. Not only has the second category fully disappeared, but unskilled employments have also continually lost significance.

The pivotal amendment which modern apprenticeship legislation has added to the foundations laid in the late nineteenth century may be seen in the involvement of both the state and the trade unions within a system which nevertheless has remained corporatist in its basic features. The fact that the Meister still represents the most valuable and significant single manual qualification in German industry is closely associated with this tradition. The status of the Meister also comprises a pedagogical function linked to the notion of the skilled craftsman who hands on his dexterity and knowledge to the younger generation. It may well be claimed that this idea is widely absent in England whose industrial pattern and tradition of skill formation have emerged from a different course of development (Dickinson \& Erben, 1985).

\subsection{The Making of the Compulsory Vocational School}

As regards in-company training, the corporatist framework established by legal sanction in the late nineteenth century was to be gradually submitted to governmental interference during the time of the Third Reich although there was no homogeneous training law until 1969. However, much earlier in the development of the dual system, compulsory attendance at the part-time vocational school had gradually emerged as the second principle underlying formalized vocational training. Fortbildungsschulen (continuation schools) had been made obligatory as early as 1869 when the Gewerbeordnung mentioned above provided for compulsion but left it to individual communities to pass by-laws for this purpose. The Act of 1897, in contrast, saw it as part of the newly-defined duties of the guilds and chambers to found and maintain continuation schools for craft apprentices. It also clearly stipulated that apprentices had to be released from work to attend such a school and masters were obliged to ensure they did so (Schöfer, 1981, pp. 176-178). Nevertheless, the overall picture of legal provisions concerning the continuation school in the nineteenth century yields the impression of voluntariness on a large scale. Its curriculum, too, could hardly be described as paying attention to the respective occupations of those who went there. In the majority of cases continuation schools were concerned with elementary education rather than moving into the vocational sphere (Blankertz, 1982, p. 205).

We now turn our thoughts to Georg Kerschensteiner (1854-1932), widely held to be the "father of the German vocational school", by quoting Simons who regards Kerschensteiner's progressing "to the state of action" and seeing "that his plans were put into force" (Simons, 1966, p. 124) as the central momentum in the evolution of the German compulsory vocational school system. His idea of bridging the gap between the end of the elementary school (Volksschule) and the beginning of military service by establishing vocational schools for school-leavers was based on the conviction that "education for the ordinary man and woman must be woven into the practical work of life" (Higginson, 1990, p. 248). The continuation school's purpose was to complement workshop training and Kerschensteiner linked it to the idea of Beruf, which in his eyes stood for the major route to Menschenbildung (education of the individual) - an ideal recurring back to Humboldt and associated with the concept of academic education as it emerged in the course of the nineteenth century (Blankertz, 1982, p. 89). Kerschensteiner conceived 
of the individual as essentially a social being, both with respect to his occupation and to his citizenship within the community. This meant a complete break with traditional educational thinking (Simons, 1966, p. 28). If the Act of 1897 may be seen as key event in the history of the dual system as far as in-company training is concerned, Kerschensteiner's Prize Essay delivered to the Erfurt Academy of Sciences in 1901 (Kerschensteiner, 1901) must be seen to comprise thoughts that were to be of revolutionary significance for the German school system.

Kerschensteiner's ideas became practice after he, formerly a teacher of mathematics and physics, had been appointed Director of Education in Munich in 1895. Between 1900 and 1906 the continuation school system there underwent fundamental changes. Kerschensteiner saw that the necessary steps were taken to establish obligatorische fachliche Fortbildungsschulen (obligatory continuation schools linked to specific occupations) to replace the general continuation school which was disliked by masters and teachers and which apprentices experienced as a nuisance and burden. By 1906 some fifty schools on the new model had been founded (Abel \& Groothoff, 1959, p. 89). Kerschensteiner was convinced that the Berufsschule held invaluable advantages against an extension of the school leaving age (which was then 14) since it was cheaper and more efficient both in social and educational terms (Kerschensteiner, 1966, p. 158). It is important to observe that Kerschensteiner's school reform gained momentum because it was an educational scheme which, although it had to be wrested from the masters and employers who saw it as a rival institution interfering with practical training, complied well with the idea of the Staatsbürger (citizen) whom the Empire's political élite wanted and needed (Blankertz, 1969, pp. 135-138).

In Prussia, too, the trade continuation school increasingly became the typical pattern of post-compulsory education for apprentices and young wage-earners. During the "take-off", between 1895 and 1914, the number of Prussian trade continuation schools rose from 761 to 1900 . Besides pedagogical motives, in Prussia even more than in Bavaria, the state developed a major national interest in education and, by making these establishments mandatory (though only via community by-laws), held that schools were crucial factors of social stability (Greinert, 1990). There is no doubt that in Prussia, in particular, the concept of the compulsory continuation school can be attributed to those socio-political parameters which had smoothed the way for the restitution of the ancient apprenticeship system. When looking at the first vocational schools in Munich it becomes evident that here, too, the guild tradition lived on, since it was Kerschensteiner who above all believed in the educative value of practical work (Simons, 1966, pp. 48-52): The workshop with the Meister was considered as important a "learning venue" as the vocational school which, besides equipping the young worker with useful knowledge and a sound moral attitude as a citizen, should also make provision for practical training in the Schulwerkstatt.

As a matter of fact, compulsory attendance at the Berufsschule for 14-year-olds on a national scale did not materialize until 1938. The Compulsory School Attendance Act (Reichsschulpflichtgesetz) required apprentices and juvenile employees to be released from work and subjected employers to fines or even imprisonment in the case of non-observance. The part-time vocational school had to be attended for a period of three years (or two years in the case of agricultural occupations). In 1940, the Ministry of Science and People's Education fixed its share of vocational training to 6-8 hours a week (Kümmel, 1980, pp. 278-280). Certainly the compulsory vocational school was seen as a vehicle of nationalsozialistische Erziehung as well as the other institutions which were geared to the goals of the Nazi regime. However, the idea itself was not a new one. The 
Weimar Constitution in 1919 provided for the continuation school ending at the age of 18 as part of general compulsion and demanded ensuing legislative action by the states. As the Länder raised their objections the proposed Reichsberufsschulgesetz (Vocational Schools Act) of 1920 failed to materialize, mainly for financial reasons. (There certainly is a parallel to the British Fisher Education Act). In the same year, however, the National School Conference (Reichsschulkonferenz), which took place in Berlin, for the first time mentioned the term Berufsschule as a label for the mandatory continuation school based on the pattern developed by Kerschensteiner (Reichsministerium des Innern, 1921, pp. 715, 721). In Southern Germany, however, the names Gewerbeschule (trade school) and Handelsschule (commercial school) continued to be commonly used (Muth, 1985, p. 493).

In essence, the modern vocational school in Germany follows the principles underlying the concept of the great school reformer although the didactics of Staatsbiirgererziehung (education of the citizen) have been replaced by a more realistic approach to widening the vocational and general theoretical skills of apprentices. As to the legal aspect, the provisions included into the 1938 Act which led to part-time compulsion were transferred into the school acts of the Bundesländer of the Federal Republic after 1949.

\section{England's Way: taking over from the Industrial Revolution}

The history of vocational training in England [3] may be subdivided into four phases. The first refers to the apprenticeship system of the guilds which arose in the twelfth century. The second period covers the two and a half centuries between the enactment of the Statute of Artificers in 1563 and its repeal by Parliament in 1814. The third phase marks what may be labelled the "time of laissez-faire", ending with the Industrial Training Act in 1964. The fourth period marks the increasing commitment on the side of the government which resulted in the passing of two major training acts and gave birth to the YTS as a state-supported segment within the training sector.

\subsection{The Decline of the System of Apprenticeship}

In 1563, the Statute of Artificers formalized the system of guild apprenticeship by establishing what could be described as a national manpower and employment policy (Perry, 1976, p. 6). Having served an apprenticeship, under a properly qualified master, was made the central prerequisite for obtaining "freedom of the trade" within a city or town. As the guilds had always sought to restrict competition by regulating the number of craftsmen entering the trade as well as the length of the apprenticeship this meant sticking with an ancient tradition. The exclusive function of skilled apprenticeship is shown clearly in the key provision of the Statute which stipulates that "it shall not be lawful to any Person .... to set up, occupy, use or exercise any Craft, Mystery or Occupation, ..., except he shall have been brought up therein seven Years at the least as an Apprentice ..." (Statutes at Large, 1786, p. 532). As a matter of fact, the Act extended the London custom of indentured apprenticeship to the whole country. It limited the number of journeymen and apprentices that could be employed by a single master and put restrictions on those who could take or wanted to become apprentices. The execution of the statute was to be in the hands of the Justices of the Peace (Nef, 1957, p. 26).

There was a number of motives which led to the enactment of the Statute of Artificers. Besides the wish to preserve social stability the Elizabethan state sought to increase the 
prosperity of the crown by promoting commerce and the crafts (Dunlop, 1912, p. 60). But the Act also was a "triumph of the craft-guilds" since it tended to stabilize the economic and social function of the corporations (Jevons, 1887, p. 34). Even after the Industrial Revolution had swept away most of the old order of medieval craftsmanship the provisions of the Statute of Artificers were "increasingly called in aid by workmen pleading for the determination of a living wage" (Perry, 1976, p. 9). However, with free craftsmanship becoming the general rule in England, the system was in decline long before it was repealed. As a matter of fact, from the late seventeenth century, control of obedience to the law had been taken over by the guilds and companies themselves. As new industries and trades were growing up that were not under guild observance it was logical that the system was never able to take roots in sectors such as the cotton industry (Dunlop, 1912, p. 229). Adam Smith argued that the Act had been effectively applied only in those trades already in existence at the time of its enactment and that its operation had been limited to market towns, "it having been held that in country villages a person may exercise several different trades, though he has not served a seven years apprenticeship to each" (Smith, 1963, p. 96). The erosion of the obligatory system of apprenticeship was also due to the unwillingness of Crown and Parliament to protect it against the emerging spirit of capitalism. As Clapham suggests, the courts, too, were against economic interference: "From James I's days they held that Common Law stood for freedom" (Clapham, 1951, p. 256).

According to Toynbee the "Wealth of Nations and the steam engine ... destroyed the old world and built a new one" (Toynbee, 1908, p. 204). During the late eighteenth and early nineteenth centuries production methods changed fundamentally by moving from the workshop into the mill and factory (Mantoux, 1962). Especially in the cotton industry, England's leading industrial branch, skilled craftsmen could easily be substituted by unskilled or semi-skilled labourers, predominantly women and children. Here the working classes were seen as part of the free-market system in the same way as the employer who felt that the restrictions of the Elizabethan code restrained the free circulation of labour from one employment to another. Adam Smith was the main protagonist of those who attacked the Statute of Artificers as not complying with the needs of the time. Besides complaining of the "exclusive privileges of corporations" he maintained that to hinder a man from employing his dexterity "in what manner he thinks proper without injury to his neighbour, is ... a manifest encroachment upon the just liberty both of the workman, and of those who might be disposed to employ him" (Smith, 1963, pp. 97, 108).

With reference to apprenticeship the impacts of the Industrial Revolution have to be looked at from two points of view:

(i) The old order had already been eroded before the Industrial Revolution began to change the English economy and with it the social framework which supported the apprenticeship system. However, in the wake of the emergence of new branches of industry the apprentice gave way to the child or youth who worked alongside men and women in the textile factories that were the visible signs of the new age. The decline of apprenticeship was accelerated by those regulations of the Elizabethan Poor Law which produced the custom of "binding out" parish apprentices to employers for the purpose of relieving the burden on local poverty funds (George, 1985 , p. 213). It was the first Factory Act of 1802 which predominantly dealt with these children, many of whom had, by then, been "apprenticed out" to the cotton and woollen factories where they did not enjoy the same protective status as 
ordinary apprentices (Hutchins \& Harrison, 1966, pp. 14-18). During the nineteenth century child labour remained an ubiquitous phenomenon. Robert Owen wrote in 1815 that in the manufacturing districts "it is common for parents to send their children of both sexes at seven or eight years of age, ..., to enter the manufactories" (Owen, 1967, p. 40). In Manchester, in 1851, 60\% of 13-year-olds and $76 \%$ of 14-year-olds were in employment, mainly in the textile industry (Anderson, 1978, p. 75).

(ii) As to the legal side, the Elizabethan Labour Code remained valid until 1814. When the "apprenticeship campaign" of 1813/14 commenced, the cause ironically was brought before Parliament by the supporters of the Act who asked for the maintenance of the old industrial legislation (Prothero, 1979, pp. 51-61). Masters and journeymen who had formed the backbone of the ancient guild organisation were more and more standing up against each other by requesting the House to decide in compliance with their respective interests. Whereas those masters who had become capitalist employers saw the interest of the community advanced by "throwing open the market of industry" (quoted in Galton, 1896, p. 112), the journeymen claimed that "the apprenticed artisans have, collectively and individually, an unquestionable right to expect the most extended protection from the Legislature" (quoted in Bland et al., 1914, p. 588). The "apprenticeship campaign" forms the "last chapter in the history of compulsory apprenticeship" (Dunlop, 1912, p. 240). Since the liberal arguments proved to be more convincing than those stressing the value of trade regulations, Parliament eventually repealed the Act by stipulating that no one was to be prosecuted if he practised a trade without having served an apprenticeship (Derry, 1931/32). The Municipal Corporations Act passed in 1835 added to this by lifting the privileges of companies. It was enacted that any citizen in any community was free to keep a shop or pursue a trade without being a freeman (Kramer, 1927, p. 180).

The decline of apprenticeship both in reality and in the Statute Books can be regarded as a crucial cause of the dichotomy of "boy learners" and "boy labourers" typical for the situation of vocational training at the beginning of our century. Whereas for the first group an apprenticeship made sure that the boy was "at once learning and earning" and was getting "his education by being allowed to execute operations which have a market value" (Tawney, 1909, p. 519), the second class consisted of those "who are not apprentices or learners but who are being employed solely with a view to the present utility of their labour" (ibid., p. 524). Richard H. Tawney, the social reformer, referred to a social as well as an educational problem when claiming that the majority of boys entered the labour market via "non-educational employments" (ibid., p. 525). He also pointed to the dependency of youth unemployment on the quality of formalized industrial training. As a matter of fact, the latter would only be found among an exclusive range of occupations of the so-called "Labour Aristocracy" whose members had traditionally sought to assert monopolies through demarcation of occupations and types of training (Hobsbawm, 1964). Yet even here it was perpetually losing its significance as an instrument of industrial relations (Webb \& Webb, 1920, p. 455). Tawney summarized his findings (Tawney, 1909, p. 535) by stating

(1) that among large sections of boys the character of the work done is such as to make it difficult for them to find employment when displaced at manhood, and in some cases such as actually to demoralise them; (2) that as a matter of fact the influence of these tendencies is visible in the records of 
juvenile crime and unemployment.... : (3) that these conditions do not tend to correct themselves.

As a result of the Industrial Revolution and the predominance of liberalism in England the craft tradition with its social and educational implications enshrined in the system of apprenticeship and protected by law survived much more selectively than in Germany (Lane, 1987, p. 63) where the dual system originated in its revival.

\subsection{The Continuation School and the Problem of Compulsion}

Unlike in Germany, where the state restored the legal framework for apprenticeship at the end of the nineteenth century and where, more recently, it plays a crucial role in defining and standardizing training, in England there has been avoidance of recognizing "occupational boundaries outside the firm" due to the importance of internal labour markets within companies (Loveridge, 1983, p. 51). Yet the deskilling of labour processes in the wake of industrialization, which made it easy to give up systematic training, traditionally had also been linked to a denial of "education after compulsion" for those entering employment. For an analysis of this aspect it is necessary to take a close look at the evolution of the educational system in England and, even closer, at the continuation school, the function of which, as in Germany, was to deliver education to apprentices and young workers.

During the Victorian Age the idea of universal education was widely opposed as a matter of principle since economic and political liberalism did not restrict their influence to bringing down the old apprenticeship system (Williams, 1967, p. 229). If the year 1814 marks the withdrawal of the state from the regulation of trade and industry, the "unwillingness to take initiatives leading to change" can be clearly illustrated by referring to the role of the British government in education (Stephens \& Roderick, 1973, p. 149). Although neither ignoring the "Condition-of-England Question" nor opposing the cause of popular education, the leading figure of liberalism in Victorian England, John Stuart Mill, maintained that the idea of a "paternal system of government" collided with the liberal principle of restricting the government's duties to the area of "unauthoritative interference" (Mill, 1968, pp. 942-945). Mill regarded laissez-faire as the "general rule" and considered that, even with respect to education, it ought not to be desirable "that anything should be done by funds derived from compulsory taxation, which is already sufficiently well done by individual liberality" (ibid., p. 949). There can be no doubt that the development of elementary education in England and Wales in the nineteenth century was strongly influenced by the prevalent socio-political dogma of the Victorian Age.

Its history begins with the charity schools of the eighteenth century and proceeds with the emergence of the Sunday and monitorial schools, which also worked on a voluntary basis and became devoted to the schooling of the lower orders. Churches and voluntary organisations remained the most powerful agents of popular education even after the passing of the 1902 Education Act and their contribution to the decrease of illiteracy must not be underestimated. In contrast, the Factory Acts mark the actual beginning of compulsory education as they were directed to fixing the hours during which children at work had to be taught. The combination of elementary instruction and manual work became known as the "half-time system of education". It was universally implemented by the 1844 Factory Act and as a matter of fact lingered on until 1918. It may well be regarded as impeding the development and spread of effective institutions concerned 
with full-time elementary education. Obedience to the Factory Acts was poor and the system failed to work efficiently, not least because it subjected educational objectives to the needs of factory employment. Since it was an adjunct to child labour it became prominent above all in the industrial counties of North West England. A. J. Mundella called its underlying theory "one of the most preposterous fallacies ever trotted out by an interested class to hoodwink the community" (quoted in Silver, 1979, p. 157).

In 1870 , following its main protagonist's speech before Parliament, the Forster Education Act made provisions for state schools to complement the voluntary system. William E. Forster, Vice President of the Education Department, had warned that "upon the speedy provision of elementary education" depended the country's industrial prosperity (quoted in Maclure, 1979, p. 104). Compulsory elementary schooling, however, did not materialize until 1876 and 1880 respectively. As to England's time lag against the continent, it is revealing to quote the Samuelson Report of 1884 (Stephens \& Roderick, 1973, p. 161):

In two very important respects, however, the education of a certain proportion of persons employed in industry abroad, is superior to that of English workmen; first, as regards the systematic instruction in drawing given to adult artizans, more especially in France, Belgium and Italy; and secondly, as to the general diffusion of elementary education in Switzerland and Germany.

The fate of the continuation school in England is closely linked to the attention the issue of education received from the government as a whole. As a matter of fact, continuation schools were widely seen to compensate for the deficiencies of elementary education. They were far from the Cross Commission's recommendation in 1888 that they should avail of "special schedules of standards and subjects" which should be "suited to the needs of the locality" (quoted in Cowan, 1970, p. 42). Although Whitehall had become a serious agent of elementary education by 1899 (Board of Education Act) the continuation schools remained a stepchild of educational policy, mainly for two reasons: Firstly, they were not seen as indispensable to the country's well-being in economic terms as were the elementary schools, the secondary schools, the universities or even the fledgling system of Technical Education which had come to profit from governmental subsidies with the passing of the Technical Instruction Act of 1889 . Secondly, the continuation school had traditionally been part of the voluntary system of Further Education which had emerged with the first Mechanics' Institutes and Literary Societies at the end of the eighteenth century. Therefore it appeared to be reasonable to leave it to the workman himself whether he wanted to promote his knowledge without his actual employment (Sadler, 1908, p. 4). Abbott argues that the voluntariness of school attendance within the system of Further Education had always been linked to a traditional British attitude which was "against using the school for imparting skills in manual occupations and in favour of confining the instruction to teaching undergoing principles" (Abbott, 1933, p. 61). The Samuelson Commission, too, held the belief that the country's workshops were "really the best technical schools in the world" and that extending technical instruction or the teaching of science beyond the elementary or secondary school would take away the advantages of practical learning from the practical man (quoted in Maclure, 1979, p. 24).

As to compulsion, however, two major Education Acts of our century paid tribute to the idea of continuation schools for 14-16-year-olds on the German model (Curtis \& Boultwood, 1970, p. 181). The Fisher Education Act raised the compulsory school leaving age to 14 years and made provision for school leavers to attend a "day 
continuation school" for as many as 320 hours p.a. Financial constraints in the wake of the First World War, however, led to its abandonment. The same happened again in 1944 when the Butler Education Act, which re-affirmed the scheme of obligatory continuation schools, turned out to be a dead letter in this respect. The so-called "County Colleges" for 15-18-year-olds were to provide part-time instruction to the equivalent of 330 hours p.a. However, the new schools failed to materialize in all but a few "isolated Local Education Authorities" (Perry, 1976, p. 19). Although the Act extended the responsibilities of LEAs onto the field of Further Education and thus required them to secure adequate facilities for young people over compulsory school age, the idea of the day continuation school had virtually been shelved when the War ended (Evans, 1978, pp. 98, 105). Hence in this field practice is still lagging behind positive legislation. It may be speculated whether this is going to change in the foreseeable future. The following comment once again refers to the divergent development of Germany. It dates back to 1966 but appears to be still valid for our time (Simons, 1966, p. 124):

After more than twenty years these laws have not come to fruition and England still remains without some system of compulsory part-time education for young people under eighteen. How much longer are we to persist in this folly of passing laws and of ignoring them, of refusing to insist that all young people be given the opportunity to improve themselves both in their capacity as workers and as citizens in a democracy? At the beginning of the century Kerschensteiner achieved far more than we have done until now, for, whereas in England we are still at the stage of discussions and plans and laws, he progressed to the stage of action and saw that his plans were put into force.

\section{Conclusion}

The features of vocational training in England and Germany both represent an "updated past" because they follow the principles of vocational training as they emerged from the time of the Industrial Revolution. In England, then, vocational training in the majority of cases meant acquiring qualifications through on-the-job training which could be complemented by the voluntary attendance of evening classes in continuation schools. As a matter of fact, industrial training never became successfully institutionalized within the national educational system: partly because the division of education and training typical of the Victorian Age continued to paralyse the development of educational opportunities for the working classes; partly because the Industrial Revolution had resulted in shaping a pattern of industrial training being that of "boy labourers" rather than of "boy learners". Whereas in Germany the state emerged as the leading force in promoting vocational training, in England, due to the successes of industrialisation achieved without any significant contribution of the educational system, it was held common belief that "preparation for production was best given on the job rather than in formal education" (Child et al., 1983, p. 73). The general aversion from state intervention and the reluctance on the government's side to become involved with matters linked to skill formation in particular also stifled efforts to institutionalise the day continuation school on a compulsory basis. In Germany, due to a decidedly corporatist approach to vocational training and to Kerschensteiner's achievements as regards the compulsory vocational school, industrial training remained linked to the notion of Beruf which can also be seen as the crucial trait of the German pattern of work organisation. Besides demanding from its owner systematic acquisition of marketable skills its dominant 
feature is that it has severed the close connection between specific workplaces and the process of skill formation which prevails in England.

Correspondence: Thomas Deissinger, Universität Mannheim, Lehrstuhl Erziehungswissenschaft I, D-68131 Mannheim, Germany.

\section{NOTES}

[1] My information is based on a short passage in CEDEFOP flash special, No. 4/1992, p. 7. I regret that I did not avail of the Training Surveys when preparing this article.

[2] The meaning of the term Beruf extends to more than just a trade or occupation in the narrow sense. It also means vocation or profession and has been linked to the notion of somebody's calling into a specific employment. Historically, its connotations embrace both social (the idea of Stand, i.e. station in society) and individual aspects (the idea of having a vocation to which the individual feels inclined).

[3] Whenever in the following two sections historical facts have not been explicitly attached to sources of literature I have referred to my doctoral thesis (Deissinger, 1992).

\section{REFERENCES}

Аввотт, A. (1933) Education for Industry and Commerce in England (London, Oxford University Press). ABEL, H. \& GroothofF, H.H. (1959) Die Berufsschule. Gestalt und Reform (Darmstadt, Carl Winter).

Anderson, M. (1978) Family Structure in Nineteenth Century Lancashire, 2nd edn (Cambridge, Cambridge University Press).

BENNER, H. (1977) Der Ausbildungsberuf als berufspädagogisches und bildungsökonomisches Problem (Hannover, Schroedel).

BenNer, H. (1987) Arbeiten zur Ordnung der Berufsausbildung vom DATSch bis zum BiBB, in: W.-D. GREINERT et al. (Eds) Berufsausbildung und Industrie. Zur Herausbildung industrietypischer Lehrlingsausbildung, pp. 269-293 (Berlin, Bundesinstitut für Berufsbildung).

Blackbourn, D. (1977) The Mittelstand in German society and politics, 1871-1914, Social History, 4, pp. $409-433$.

Bland, A.E., Brown, P.A. \& TaWney, R.H. (Eds) (1914) English Economic History. Select Documents (London, G. Bell \& Sons).

BLANKERTZ, H. (1969) Bildung im Zeitalter der großen Industrie. Pädagogik, Schule und Berufsausbildung im 19. Jahrhundert (Hannover, Schroedel).

BLANKeRTZ, H. (1982) Die Geschichte der Pädagogik: Von der Aufklärung bis zur Gegenwart (Wetzlar, Büchse der Pandora).

BUNDESMINISTER FUR BILDUNG UND WISSENSCHAFT (1992) Grund-und Strukturdaten 1992/93 (Bad Honnef, Karl Heinrich Bock).

CALLENDER, C. (1992) Will NVQs work? Evidence from the Construction industry, IMS Report No. 228 (Brighton, Institute of Manpower Studies).

CASEY, B. (1983) Integrating young persons into work, Policy Studies, pp. 170-183.

CHILD, J., Fores, M., GLover, I. \& LAWReNCE, P. (1983) A price to pay? Professionalism and work organization in Britain and West Germany. Sociology, 17, pp. 63-78.

Clapham, J. (1951) A Concise Economic History of Britain. From the Earliest Times to 1750 (Cambridge, Cambridge University Press).

COWAN, I.R. (1970) Elementary evening schools and the evening continuation school movement in Salford from 1862 to 1903, Vocational Aspect of Education, 22, pp. 41-47.

CurTIS, S.J. \& Boultwood, M.E.A. (1970) An Introductory History of English Education since 1800, 4th edn (London, University Tutorial Press).

DEISSINGER, TH. (1992) Die englische Berufserziehung im Zeitalter der Industriellen Revolution. Ein Beitrag zur Vergleichenden Erziehungswissenschaft (Würzburg, Königshausen \& Neumann).

DENT, H.C. (1983) Education in England and Wales, 2nd edn (London, Hodder \& Stoughton).

Department of EDUCATION and Science (1988) Education Statistics for the United Kingdom (London, HMSO). 
DERRY, T.K. (1931/32) The repeal of the apprenticeship clauses of the statute of apprentices, Economic History Review, 3, pp. 67-87.

Deutscher Ausschuss für das ERziehungs. und BILdUngswesen (1966) Gesamtausgabe der Empfehlungen und Gutachten (Stuttgart, Klett).

Dickinson, H. \& ERBEN, M. (1985) An aspect of industrial training in the Federal Republic of Germany: sociological considerations on the role of the Meister, Joumal of Further and Higher Education, 9. pp. 69-76.

DUNFORD, J. \& SHARP, P. (1990) The Education System in England and Wales (London, Longman).

Dunlop, O.J. (1912) English Apprenticeship and Child Labour. A History (London, Fisher Unwin).

ELEY, G. (1978). The Wilhelmine right: how it changed, in: R. J. Evans (Ed.) Society and Politics in Wilhelmine Germany, pp. 112-135 (London, Croom Helm).

ELLIS, P. \& GoRrINGE, R. (1989) Continuing education and training through competence-based vocational qualifications, Educational and Training Technology International, 26, pp. 7-13.

ElSER, W. \& KRAMER, O. (1987) Grundriss des Schulrechts in Baden-Württemberg, 2. Aufl. (Neuwied, Luchterhand).

Evans, K. (1978) The Development and Structure of the English Educational System (London, Hodder \& Stoughton).

Galton, F.W. (Ed.) (1896) Select Documents Illustrating the History of Trade Unionism: I. The tailoring trade (London, Longmans, Green).

George, M.D. (1985) London Life in the Eighteenth Century (Harmondsworth, Penguin).

GREINERT, W.-D. (1988) Marktmodell-Schulmodell-duales System. Grundtypen formalisierter Berufsbildung, Die berufsbildende Schule, 40, pp. 145-156.

GREINERT, W.-D. (1990) Fortbildungsschulpolitik im Deutschen Kaiserreich. Die wichtigen Jahre von 1895 bis 1914, in: I. Lisop, W. .D. Greinert \& K. StratmanN (Eds) Gründerjahre der Berufsschule, pp. 177-192 (Berlin, Bundesinstitut für Berufsbildung).

HEATON, H. (1964) Economic History of Europe, rev edn (New York, Harper \& Row).

Higgrnson, J.H. (1990) Michael Sadler and the German Connection, Oxford Review of Education, 16, pp. $245-253$.

Hгтснсоск, G. (1988) Education and Training 14-18: a survey of new initiatives (London, Longman).

НовSвашм, E.J. (Ed.) (1964) The labour aristocracy in nineteenth-century Britain, in: Labouring Men. Studies in the History of Labour, pp. 272-315 (London, Weidenfeld \& Nicholson).

Hough, J.R. (1987) Education and the National Economy (London, Croom Helm).

Hurrelmann, K. \& Roberts, K. (1991) Problems and solutions, in: J. BynNeR \& K. Roberts (Eds) Youth and Work: transition to employment in England and Germany, pp. 229-250 (London, Anglo-German Foundation).

Hutchins, B.L. \& Harrison, A. (1966) A History of Factory Legislation, 3rd edn (London, Cass).

Jevons, W.S. (1887) The State in Relation to Labour (London, Macmillan).

KerschensteIner, G. (1901) Staatsbürgerliche Erziehung der deutschen Jugend. Gekrönte Preisarbeit (Erfurt, Villaret).

KERSCHENSTEINER, G. (1966) Der Ausbau der Berufsschule im deutschen Bildungswesen (1928/29), in: Berufsbildung und Berufsschule. Ausgewählte pädagogische Schriften, Bd I, pp. 147-160 (Paderborn, Schöningh).

KIESEWETTER, H. (1989) Industrielle Revolution in Deutschland, 1815-1914, (Frankfurt a.M., Suhrkamp).

Kramer, St. (1927) The English Craft Gilds. Studies in their Progress and Decline (New York, Columbia University Press).

KüMmEL, K. (1980) Zur schulischen Berufserziehung im Nationalsozialismus, in: M. HEINEMANN (Ed.) Erziehung und Schulung im Dritten Reich, Teil I: Kindergarten, Schule, Jugend, Berufserziehung, pp. 275288 (Stuttgart, Klett-Cotta).

KutsCHA, G. (1990) Öffentlichkeit, Systematisierung, Selektivität-Zur Scheinautonomie des Berufsbildungssystems, in: K. HARNEY \& G. PÄTZOLD (Eds) Arbeit und Ausbildung. Wissenschaft und Politik pp. 289-304 (Frankfurt, Verlag der Gesellschaft zur Förderung arbeitsorientierter Forschung und Bildung).

LANDES, D.S. (1969) The Unbound Prometheus. Technological Change and Industrial Development in Western Europe from 1750 to the Present (Cambridge, Cambridge University Press).

LANE, C. (1987) Capitalism or culture? A comparative analysis of the position in the labour process and labour market of lower white-collar workers in the financial services sector of Britain and the Federal Republic of Germany, Work, Employment and Society, 1, pp. 57-83.

LAYARD, R. \& PRAIS, S.J. (1990) Employment training: time to think about compulsion, Financial Times, No. $31,099,15$ March, p. 23. 
LEwIS, A.M. (1981) Descriptions of the Vocational Training Systems: United Kingdom (Berlin, CEDEFOP). LIEPMANN, K. (1960) Apprenticeship. An Enquiry into its Adequacy under Modern Conditions (London, Routledge \& Kegan Paul).

LOVERIDGE, R. (1983) Sources of diversity in internal labour markets, Sociology, 17, pp. 44-62.

LowE, J. (1992) Education and European Integration, International Review of Education, 38, pp. 579-590. MACLuRE, J.S. (Ed.) (1979) Educational Documents. England and Wales, 1816 to the Present Day, 4th edn (London, Methuen).

Mantoux, P. (1962) The Industrial Revolution in the Eighteenth Century. An Outline of the Beginnings of the Modern Factory System in England (London, Cape).

MARSDEN, D. \& RYAN, P. (1991) Initial training, labour market structure and public policy: intermediate skills in British and German industry, in: P. RYAN (Ed.) International Comparisons of Vocational Education and Training for Intermediate Skills, pp. 251-285 (London, Falmer Press),

MARX, K. (1974) Das Kapital. Kritik der politischen Ökonomie (1867), Bd 1 (Berlin, Dietz).

MatHieson, M. (1992) From Crowther to core skills, Oxford Review of Education, 18, pp. 185-199.

MiLL, J.S. (1968) Principles of Political Economy with Some of their Applications to Social Philosophy (1848) Collected Works, Vol. III, Book III-V, J. M. RoBson (Ed.) introduction by V. W. BLADEN (London, Routledge \& Kegan Paul)

MÓLLER, J.B. (1989) Deutschland und der Westen (Berlin, Duncker \& Humblot).

MUTH, W. (1985) Berufsausbildung in der Weimarer Republik (Stuttgart, Franz Steiner).

N.N. (1988) Economic activity and qualifications, Employment Gazette, October, pp. 549-563.

NEF, J.U. (1957) Industry and Government in France and England, 1540-1640 (Ithaca, NY, Cornell University Press).

NIPPERDEY, TH. (1990) Deutsche Geschichte, 1866-1918, Bd 1, Arbeitswelt und Bürgergeist (München, C. H. Beck).

NOAH, H.J. \& ECKSTEIN, M.A. (1988) Business and industry involvement with education in Britain, France and Germany, in: J. LAUGLO \& K. LILLIS (Eds) Vocationalizing Education. An International Perspective, pp. 45-68 (Oxford Pergamon).

OWEN, R. (1967) Observations on the effect of the manufacturing system: with hints for the improvement of those parts of it which are most injurious to health and morals (1815), in: A Supplementary Appendix to the First Volume of the Life of Robert Owen, Vol. 1A, pp. 33-45 (New York, A. M. Kelley),

PAGE, G.T. (1967) The Industrial Training Act and After (London, Andre Deutsch).

PERRY, P.J.C. (1976) The Evolution of British Manpower Policy from the Statute of Artificers 1563 to the Industrial Training Act 1964 (London, BACIE).

PRAIS, S.J. (Ed.) (1989) Productivity, Education and Training: Britain and Other Countries Compared. Reprints of studies published in the National Institute Economic Review (London, National Institute of Economic and Social Research).

Prothero, I.J. (1979) Artisans and Politics in Early Nineteenth-Century London. John Gast and his Times (London, Methuen).

RAFF, D. (1987) Youth unemployment in the United Kingdom, 1979-1984, in: P. BRown \& D. N. AsHron (Eds) Education, Unemployment and Labour Markets, pp. 218-247 (London, Falmer Press).

RAGGATT, P. (1988) Quality control in the dual system of West Germany, Oxford Review of Education, 14, pp. $163-186$.

REICHSMINISTERIUM DES INNERN (1921) Die Reichsschulkonferenz 1920. Ihre Vorbereitung und ihre Verhandlungen (Leipzig, Quelle \& Meyer).

SADLER, M.E. (Ed.) (1908) Continuation Schools in England and Elsewhere. Their Place in the Educational System of an Industrial and Commercial State, 2nd edn (Manchester, Manchester University Press).

SCHLÖteR, A. \& StratMANN, K. (Eds) (1985) Quellen und Dokumente zur betrieblichen Berufsbildung, 1869-1918 (Köln, Böhlau).

SCHÖFER, R. (1981) Berufsausbildung und Gewerbepolitik. Geschichte der Ausbildung in Deutschland (Frankfurt, Campus).

SILVER, H. (1979) Ideology and the factory child: attitudes to half-time education, in: P. MCCANN (Ed.) Popular Education and Socialization in the Nineteenth Century, pp. 141-166 (London, Methuen).

Simons, D. (1966) Georg Kerschensteiner. His Thought and its Relevance Today (London, Methuen).

Sмгтн, A. (1963) An Inquiry into the Nature and Causes of the Wealth of Nations (1776), Vol. I, introduction by M. Blavg (Homewood, IL, Richard D. Irwin).

StATISTISCHES AMt DER EuRopäISCHEN GemeinsChAFten (1992) Europa in Zahlen, 3, Ausgabe (Luxemburg, Amt für amtliche Veröffentlichungen der Europäischen Gemeinschaften).

StATUTES AT LARGE (1786) Volume the Second: From the First Year of the Reign of King Edward the Fourth to the End of the Reign of Queen Elizabeth (London). 
STEPHENS, M.D. \& RODERICK, G.W. (1973) Changing attitudes to education in England and Wales, 1833-1902: the Governmental reports with particular reference to science and technical studies, Annals of Science, 30, pp. 149-164.

Stratmann, K. (1967) Die Krise der Berufserziehung im 18. Jahrhundert als Ursprungsfeld pädagogischen Denkens (Ratingen, A. Henn).

Stratmann, K. (1982) Geschichte der beruflichen Bildung. Ihre Theorie und Legitimation seit Beginn der Industrialisierung, in: H. BLANKERTZ (Ed.) Enzyklopädie Erziehungswissenschaft, Bd 9.1: Sekundarstufe II-Jugendbildung zwischen Schule und Beruf, pp. 173-202 (Stuttgart, Klett-Cotta).

Stratmann, K. (1991) Betriebliche Berufsausbildung, in: C. BeRG (Ed.) Handbuch der deutschen Bildungsgeschichte, Bd IV: 1870-1918. Von der Reichsgründung bis zum Ende des Ersten Welikriegs, pp. 371-380 (München, C. H. Beck).

StratmanN, K. \& Pätzold, G. (1984) Institutionalisierung der Berufsbildung, in: M. BaEthGe \& K. NeVERMAnN (Eds) Enzyklopädie Erziehungswissenschaft, Bd 5: Organisation, Recht und Ökonomie des Bildungswesens, pp. 114-134 (Stuttgart, Klett-Cotta).

Stratmann, K. \& Schloter, A. (Eds) (1982) Quellen und Dokumente zur Berufsbildung, 1794-1869 (Köln, Böhlau).

TAWNEY, R.H. (1909) The economics of boy labour, Economic Joumal, 19, pp. 517-537.

TOYNBEE, A. (1908) Lectures on the Industrial Revolution of the Eighteenth Century in England (London, Longmans, Green).

TwINING, J. (1992) Vocational Education and Training in the United Kingdom (Berlin, CEDEFOP).

VEBLEN, TH. (1954) Imperial Germany and the Industrial Revolution (New York, Viking).

WARNER, M. (1990) Vocational training in the UK: why copying the German model is not the answer, Financial Times, 29 January, p. 11.

WEBB, S. \& WEBB, B. (1920) Industrial Democracy (1897), with new introduction (London, Longman).

Wiruams, G. (1963) Apprenticeship in Europe. The Lesson for Britain (London, Chapman \& Hall).

WrLLIAMs, R. (1967) The social history of nineteenth century education, in: N. F. CANTOR \& M. S. WERTHMAN (Eds) The English Tradition. Modern Studies in English History, Vol. II: since 1714, pp. 228-235 (New York, Macmillan).

WINKLER, H.A. (1976) From social protectionism to national socialism: the German small-business movement in comparative perspective, Journal of Modern History, 48, pp. 1-18.

ZABECK, J. (1985) Berufliche Bildung, in: Staatslexikon, hrsg. v. d. Görres-Gesellschaft, Bd 1, 7. Aufl., pp. 669-683 (Freiburg, Herder). 